\title{
Plasma relaxin and prolactin immunoactivities in pregnancy and at parturition in the ewe
}

\author{
Gillian D. Bryant and W. A. Chamley \\ Department of Anatomy \& Reproductive Biology, John A. Burns School of Medicine, \\ University of Hawaii, Honolulu, Hawaii 96822, U.S.A. and \\ Reproductive Research Section, S.S. Cameron Laboratory, \\ Werribee, Victoria, Australia 3030
}

Relaxin is clasically a hormone of pregnancy and is considered to be responsible for the relaxation of the interpubic ligament during pregnancy in small mammals (Hall, 1960). In pigs, the relaxin bioactivity in corpora lutea and blood from pregnant and post-partum animals has been measured (Anderson, Ford, Melampy \& Cox, 1973), and a radioimmunoassay for porcine relaxin has been used for measurement of relaxin during pregnancy and parturition (Sherwood, Chang, Bevier \& Dziuk, 1975): relaxin levels rose from 3 days before parturition and reached a peak $14 \mathrm{hr}$ before birth. However, the ovaries are required throughout gestation in this species (Belt, Anderson, Cavazos \& Melampy, 1971). The pregnant sheep, like women, is not dependent upon a functional corpus luteum for the whole of gestation, but no measurements of relaxin (either bioactivity or immunoactivity) have yet been reported in these species.

\section{Methods}

These experiments were carried out with Corriedale ewes. Blood samples $(10 \mathrm{ml})$ were collected every $2 \mathrm{hr}$ from indwelling jugular vein catheters from 3 animals during Days 45 and 110 of gestation. Two other ewes were ovariectomized at 60 days of gestation and bled every $2 \mathrm{hr}$ for $24 \mathrm{hr}$ on Days 110 and 145, and then during the period of labour, parturition and for up to $24 \mathrm{hr}$ thereafter. An intact ewe was also bled every $2 \mathrm{hr}$ for $20 \mathrm{hr}$ before parturition, over the period of labour and parturition and for up to $58 \mathrm{hr}$ thereafter. In one ewe (No. 83, see Text-fig. 1), samples were collected every 2 min during expulsion of the lamb. Differences in mean hormone levels were tested for significance using Student's $t$ test (Snedecor, 1956).

Relaxin immunoactivity was measured using the technique of Bryant (1972) exactly as described except that separation of bound and free hormone was effected by a conventional double-antibody procedure (Bryant \& Stelmasiak, 1974). Levels are expressed as ng porcine relaxin (NIH-RP1)/ml, since the relaxin-like immunoactivity of sheep plasma paralleled that of this porcine standard. There is no cross-reaction in this assay with any of the known anterior and posterior pituitary hormones at levels of $1 \mu \mathrm{g} / \mathrm{ml}$. The radioimmunoassay of Bryant \& Greenwood (1968) for ovine prolactin was employed with charcoal-dextran separation of bound and free hormone. Progesterone was measured using the method of Cain et al. (1972) except that an antibody to progesterone was used instead of the pregnant guinea-pig protein; the specificity of this antiserum has been reported (Hoppen, Williams \& Findlay, 1976). For statistical analysis of the data, individual values were transferred to $\log (x+1)$ and analysed on a random block design.

\section{Results and discussion}

The prolactin and relaxin levels are shown in Table 1. In the intact ewes (Nos. 53, 37 and 118), mean levels of prolactin and relaxin were significantly higher at 110 days of gestation than at 45 days $(P<0.001, P<0.05$ respectively). In the ovariectomized animals (Nos. 15 and 18$)$ there was a progressive increase in mean prolactin levels as gestation progressed but prolactin levels were lower in these two ewes than in the intact ewes bled at the same times. Ovariectomy had no apparent effect 
Table 1. Mean \pm S.D. levels $(\mathrm{ng} / \mathrm{ml})$ of relaxin and prolactin over a 24 -hr period (samples taken every $2 \mathrm{hr}$ ) during and after gestation in intact and ovariectomized (at Day 60) ewes

\begin{tabular}{|c|c|c|c|c|c|}
\hline \multirow[b]{2}{*}{ Ewe } & \multirow[b]{2}{*}{ Hormone } & \multicolumn{3}{|c|}{ Gestation } & \multirow{2}{*}{$\begin{array}{c}\text { Post partum } \\
1 \text { day }\end{array}$} \\
\hline & & 45 days & 110 days & 145 days & \\
\hline \multicolumn{6}{|l|}{ Intact } \\
\hline \multirow[t]{2}{*}{53} & Relaxin & $23 \cdot 4 \pm 42 \cdot 0$ & $38.1 \pm 50.9$ & & \\
\hline & Prolactin & $39.5 \pm 15.5$ & $202 \cdot 1 \pm 68 \cdot 9$ & & \\
\hline \multirow[t]{2}{*}{$37^{*}$} & Relaxin & $65 \cdot 6 \pm 115 \cdot 1$ & $140 \cdot 3 \pm 297 \cdot 4$ & & \\
\hline & Prolactin & $39 \cdot 2 \pm 32 \cdot 5$ & $236 \cdot 7 \pm 342 \cdot 3$ & & \\
\hline \multirow[t]{2}{*}{118} & Relaxin & $13 \cdot 4 \pm 12 \cdot 1$ & $62 \cdot 3 \pm 41 \cdot 1$ & & \\
\hline & Prolactin & $29.9 \pm \quad 7.6$ & $77 \cdot 6 \pm 41 \cdot 0$ & & \\
\hline \multirow[t]{2}{*}{83} & Relaxin & & & $29 \cdot 9 \pm 17 \cdot 8$ & $23.3 \pm 26.8$ \\
\hline & Prolactin & & & $426 \cdot 2 \pm 151 \cdot 8$ & $495.8 \pm 142.8$ \\
\hline \multicolumn{6}{|l|}{ Ovariectomized } \\
\hline \multirow[t]{2}{*}{$15^{*}$} & Relaxin & & $76 \cdot 8 \pm 101 \cdot 2$ & $42 \cdot 5 \pm 41 \cdot 1$ & $28.0 \pm 27.5$ \\
\hline & Prolactin & & $40.1 \pm 50.8$ & $228 \cdot 2 \pm 241 \cdot 9$ & $488 \cdot 1 \pm 161 \cdot 6$ \\
\hline \multirow[t]{2}{*}{18} & Relaxin & & $44.8 \pm 38.4$ & $115 \cdot 2 \pm 104 \cdot 4$ & $37.4 \pm 46.9$ \\
\hline & Prolactin & & $19.9 \pm 7.8$ & $142 \cdot 8 \pm 190 \cdot 9$ & $180 \cdot 1 \pm 59.3$ \\
\hline
\end{tabular}

* Twin pregnancy.

on relaxin concentrations and mean levels on Day 110 did not differ significantly from those on Day 145. Changes in relaxin in these animals were not significant.

Progesterone, prolactin and relaxin concentration were measured in plasma samples from the 3 ewes bled around parturition. In all animals circulating levels of progesterone agreed with all previously reported data, falling at approximately $2 \mathrm{hr}$ before parturition. Prolactin levels rose to high values in the range $281-727 \mathrm{ng} / \mathrm{ml}$ about $24 \mathrm{hr}$ before parturition and were maintained for the duration of the experiment, as found in previous work (Chamley et al., 1973).

In both ovariectomized animals, spike elevations in circulating relaxin occurred between $48 \mathrm{hr}$ before and $24 \mathrm{hr}$ after parturition. These larger spike elevations were not seen in the intact ewe, possibly because sampling was not begun early enough. In all animals there was a sharp rise in relaxin in association with expulsion of the lamb and at this time the highest recorded plasma levels (range $176-233 \mathrm{ng} / \mathrm{ml}$ ) were reached. A detailed profile of the rise in prolactin and relaxin levels for Ewe 83 at the time of expulsion of the lamb is given in Text-fig. 1.

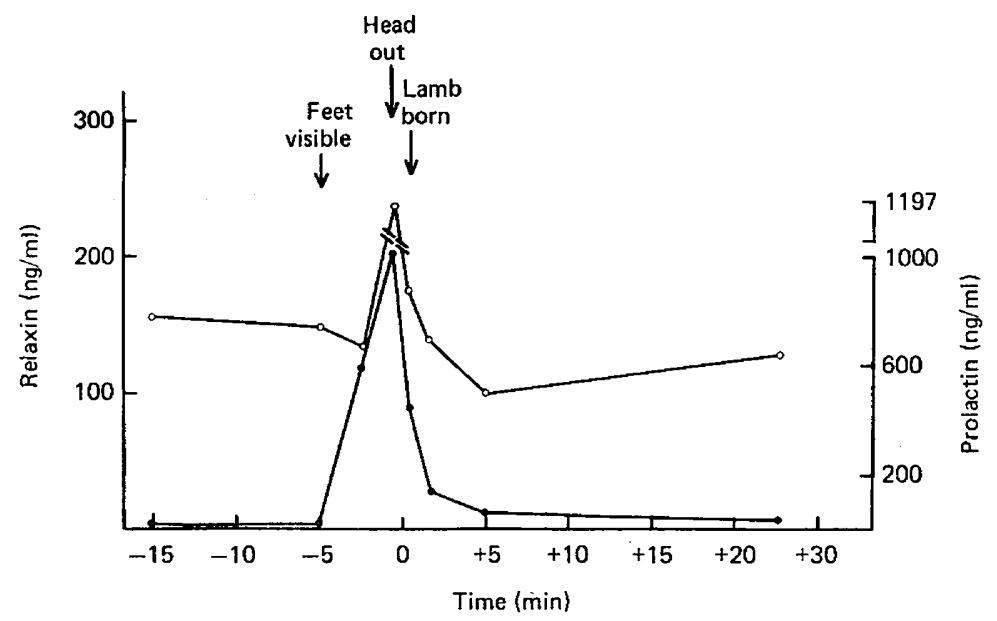

Text-fig. 1. Changes in the plasma levels of prolactin(o) and relaxin (0) of an intact ewe bled at 2-min intervals during parturition. 
It is not known whether these results differ from those obtained for pigs by Sherwood et al. (1975) because they did not continue to bleed throughout the period of birth, or whether there is a fundamental endocrine difference between these two species. This would not be surprising since the pig is polytocous and is dependent upon its ovaries for gestation, neither of which is true of the sheep.

In conflict with reports by Arai \& Lee (1967) and McNeilly (1971), our data suggest that, as pregnancy proceeds, the levels of prolactin rise in the ewe. However, their results were obtained from experiments in which blood was collected infrequently and peaks of prolactin could have been missed. An effect of ovariectomy upon circulating prolactin in the pregnant ewe has not previously been reported and this observation would seem worthy of further study.

All animals studied showed a decline in plasma relaxin immunoactivity by 1 day post partum, indicating that the uterine/placental source had been removed with the event of birth. This is the first attempt to study the acute changes in relaxin levels before parturition in any animal, and the experiments reported are a compromise compounded by the inherent difficulties of sampling before an event which is finite but which cannot be precisely forecast. Another difficulty lay in the interpretation of the results because of the constraint that the present radioimmunoassay for relaxin imposes. In pregnancy the relaxin immunoactivity measured is that from the ovaries, uterus and placenta, if indeed these are all sources of the hormone in this species (Bryant \& Stelmasiak, 1974). We attempted to differentiate between the ovarian and uterine/placental sources by studying some animals which were ovariectomized at 60 days of gestation, thereby eliminating the ovarian source of relaxin. The results suggest that the major peak of relaxin seen during expulsion of the lamb is of uterine/placental origin since the intact and ovariectomized animals showed this response, but full clarification must wait until relaxin from each source has been isolated and characterized and can be measured specifically in the presence of its counterpart.

These studies indicate that relaxin(s) may play a role in the overall control and success of sheep pregnancy and parturition and indicate that, when the methodology is available, frequent sample collection will be essential for understanding of the relative importance of the ovarian and uterine/ placental relaxins.

We thank the staff of the Reproduction Research Section, Werribee, for help during collection of the plasma samples; Mrs Nam Soon Joun for valuable technical assistance with the relaxin and prolactin assays; and Miss Eleanor Wilson for help with the progesterone assays.

The work was supported by NIH grant HD-06633, Ford Foundation Grant 66202 and the Cancer Center of Hawaii, CA-15655; G.D.B. holds a Research Career Development Award, HD 70516, and W.A.C. was supported by the Australian Wool Corporation.

\section{References}

Anderson, L.L., Ford, J.J., Melampy, R.M. \& Cox, D.F. (1973) Relaxin in porcine corpora lutea during pregnancy and after hysterectomy. Am. J. Physiol. 225, 1215-1219.

ARAI, Y. \& LEE, V.H. (1967) A double-antibody radioimmunoassay procedure for ovine pituitary prolactin. Endocrinology 81, 1041-1046.

Belt, W.D., Anderson, L.L., Cavazos, L.F. \& MelamPY, R.M. (1971) Cytoplasmic granules and relaxin levels in porcine corpora lutea. Endocrinology 89, $1-10$.

Bryant, G.D. (1972) The detection of relaxin in porcine, ovine and human plasma by radioimmunoassay. Endocrinology 91, 1113-1117.

Bryant, G.D. \& Stelmasiak, T. (1974) The specificity of a radioimmunoassay for relaxin. Endocr. Res. Commun. 1, 415-433.

Bryant, G.D. \& Greenwood, F.C. (1968) Radio- immunoassay for ovine, caprine and bovine prolactin in plasma and tissue extracts. Biochem.J. 109, 831-840.

Cain, M.D., Cerini, J.C., Cerini, M.E.D., Chamley, W.A., Cumming, I.A. \& Goding, J.R. (1972) Competitive protein-binding analysis of ovine and bovine plasma progesterone. J. Reprod. Fert. 28, 148-150.

Chamley, W.A., Buckmaster, J.M., Cerini, M.E., Cumming, I.A., Goding, J.R., OBST, J.M., Williams, A. \& Winfield, C. (1973) Changes in the levels of progesterone, corticosteroids, estrone, estradiol-17 $\beta$, luteinizing hormone and prolactin in the peripheral plasma of the ewe during late pregnancy and at parturition. Biol. Reprod. 9, 30-35.

HaLl, K. (1960) Relaxin, a review. J. Reprod. Fert. 1, $368-384$.

Hoppen, H.D., Williams, D.M. \& Findlay, J.K. (1976) The influence of prostaglandin F-2 $\alpha$ on 
pregnenolone metabolism by the autotransplanted ovary of the ewe. J. Reprod. Fert. 47, 275-281.

MCNeIlly, J.R. (1971) A solid-phase radioimmunoassay for ovine prolactin. $J$. Endocr. 49, 141149.

Sherwood, O.D., Chang, C.C., Bevier, G.W. \&
DzıUK, P.J. (1975) Radioimmunoassay of plasma relaxin levels throughout pregnancy and parturition in the pig. Endocrinology 97, 834-837.

SNedeCOR, G.W. (1956) Statistical Methods applied to Experiments in Agriculture and Biology, 5th edn. Iowa State University Press, Ames, Iowa.

Received 8 March 1976 